\title{
Effect of organic loading rates (OLR) on production of methane from anaerobic digestion of vegetables waste
}

\author{
Azadeh Babaee ${ }^{1}$, Jalal Shayegan ${ }^{2, *}$ \\ ${ }^{1}$ School of Chemical and Petroleum Engineering, Sharif University of Technology, Tehran, Iran \\ ${ }^{2}$ School of Chemical and Petroleum Engineering, Sharif University of Technology, Tehran, Iran \\ * Corresponding author. Tel: +98 2166165420, Fax: +98 2166022853, E-mail: shayegan@sharif.edu
}

\begin{abstract}
In this study, experiments were conducted to investigate the production of biogas from vegetable wastes by using anaerobic digestion process. The complete-mix, pilot-scale digester with working volume of $70 \mathrm{l}$ was used. The experimental protocol was defined to examine the effect of the change in the organic loading rate on the efficiency of the production of biogas and to report on its steady-state performance. The digester was operated at different organic feeding rates of $1.4,2$ and $2.75 \mathrm{~kg} \mathrm{VS} /\left(\mathrm{m}^{3} . \mathrm{d}\right)$. The biogas produced had methane composition of 49.7- 64\% and biogas production rates of $0.12-0.4 \mathrm{~m}^{3}$ biogas/(kg VS input). The reactor showed stable performance with highest methane and yield $\left(0.25 \mathrm{~m}^{3} \mathrm{CH} 4 / \mathrm{kg}\right.$ VS) with VS reduction of around $88 \%$ during loading rate of $1.4 \mathrm{~kg} \mathrm{VS} /\left(\mathrm{m}^{3} . \mathrm{d}\right)$. As the organic loading rate was increased, the VS degradation and biogas yield decreased. Based on data from this study, OLR of $1.4 \mathrm{~kg} \mathrm{VS} /\left(\mathrm{m}^{3}\right.$.d) is suggested as design criteria with methane production rate of $0.25 \mathrm{~m}^{3} \mathrm{CH}_{4} / \mathrm{kg}$ VS input and successful implementation of anaerobic digestion as the method of waste treatment leads to the regional utilization of renewable energy resources, energy requirements and costs.
\end{abstract}

Keywords: Anaerobic Digestion, Biogas, Methane, Vegetable Wastes

\section{Introduction}

Municipal solid waste (MSW), when landfilled, causes several environmental problems such as the biogas production, volatile organic compounds emission, leachate, public health hazard and plants toxicity [1]. In light of rapidly rising costs associated with energy supply and waste disposal and increasing public concerns with environmental quality degradation, conversion of food wastes to energy is becoming a more economically viable practice. Anaerobic digestion has become an established and proven technology as a means of managing solid organic waste [2]. Besides generating biogas for energy use, the process also destroys pathogens and produces stabilized material to be used as fertilizer in land applications. Anaerobic digestion may lead to environmental benefits with regard to waste treatment, pollution reduction, energy production and improvements in agricultural practices [3]. The amount of MSW generated in Iran is around 60000 ton/day and contains more than $70 \%$ of organic wastes. The easy biodegradable organic matter content of vegetables waste with high moisture facilitates their biological treatment and shows the trend of these wastes for anaerobic digestion [4]. Many factors affect the performance of anaerobic digestion processes. Some of them are related to feedstock characteristics, reactor design and operational conditions [5]. The organic loading rate (OLR) is an important parameter because it indicates the amount of volatile solids to be fed into the digester each day [6]. Volatile solids represent that portion of the organic-material solids that can be digested, while the remainder of the solids is fixed. The 'fixed' solids and a portion of the volatile solids are non-biodegradable. The actual loading rate depends on the types of wastes fed into the digester [6], because the types of waste determine the level of biochemical activity that will occur in the digester. The aims of this study were to investigate the influence of OLR on performance and treatment efficiency (based on volatile solids removal) of vegetable wastes digestion. 


\section{Materials and methods}

\subsection{Experimental setup}

The digester experiments were carried out in a semi-continuously pilot-scale with a total volume of 70 L. Fig. 1 illustrates the experimental set-up. The reactor was fitted with a top plate, which supported the mixer, mixer motor, gas sampler. Sampling valves were located at positions corresponding to the top, middle and bottom layer of digester contents. The reactor had one outlet at the bottom for effluent removal. The contents of the reactor were mixed as controlled by a timer, which was activated for 15min every 45 minutes. Reactor temperature was maintained at $34^{\circ} \mathrm{C}$.

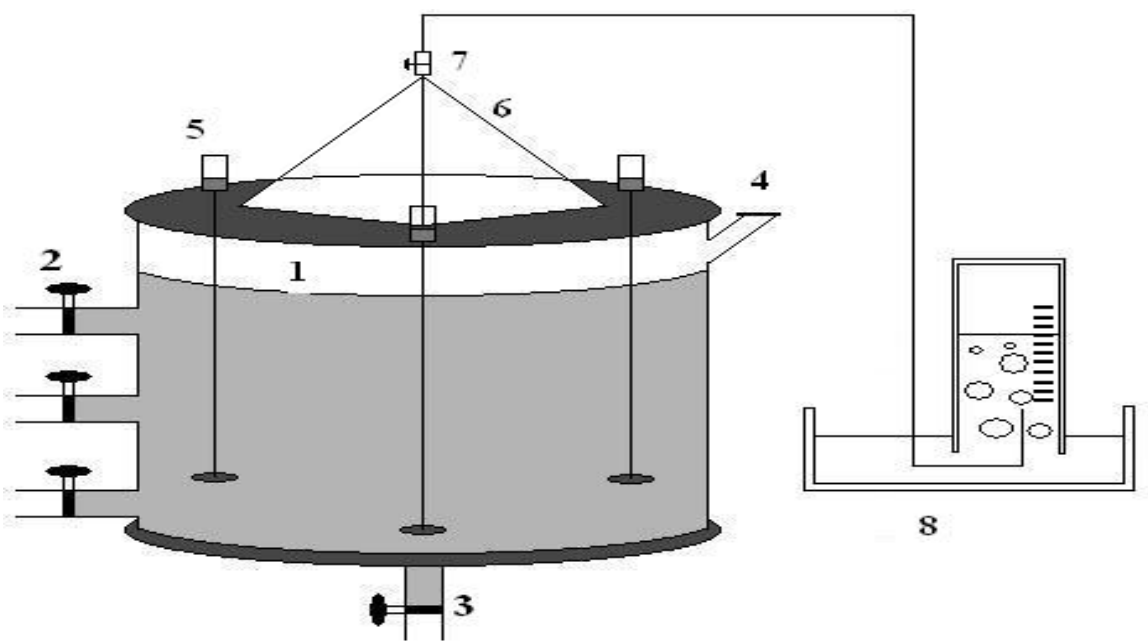

1. Digester

2. Sampling valves

3. Effluent outlet

4. Feed inlet

5. Mixer

6. Gas collector

7. Gas outlet

8. Gas measuing

(water displacement jar)

Fig. 1. The experimental set-up

\subsection{Wastes sources and characteristics}

The vegetable wastes used in this study were collected from the group market of Iran. The vegetable wastes consisted of potatoes, lettuce, tomatoes, eggplant, cucumber, and carrot to give $8-9 \%$ TS with VS content of $95-97 \%$. The COD/N ratio of vegetables waste is balanced, being around 30 and therefore, no nitrogen was added to the reactor. In fact the optimum C:N ratio for microbial activity involved in bioconversion of vegetable biomasses to methane is 25-30 [7]. The anaerobically sludge from Ekbatan wastewater treatment plant was added as seed.

\subsection{Anaerobic digester operation}

Experiments were operated in semi-continuous mode with daily feeding. Dry semi-continuous anaerobic digestion of vegetable waste was investigated in mesophilic condition with three different organic loading rates (OLR) of $1.4,2$ and $2.75 \mathrm{~kg} \mathrm{VS} /\left(\mathrm{m}^{3} . \mathrm{d}\right)$ for constant retention time of 25 days. Retention time of 25 days was maintained by feeding $2.4 \mathrm{l}$ of substrate and removing $2.4 \mathrm{l}$ of effluent daily. Table 1 shows the characteristics of each feeding rate.

Table 1: Characteristics of each feeding rate

\begin{tabular}{lccccc}
\hline & $\begin{array}{c}\text { Organic } \\
\text { loading rate } \\
\left(\mathrm{kg} \mathrm{VS} / \mathrm{m}^{3} . \mathrm{d}\right)\end{array}$ & \%TS & \%VS & $\begin{array}{c}\text { Wet waste } \\
(\mathrm{kg} / \mathrm{d})\end{array}$ & $\begin{array}{c}\text { Inlet COD } \\
(\mathrm{mg} / \mathrm{l})\end{array}$ \\
\hline Loading rate 1 & 1.4 & 8.9 & 95 & 1 & 2150 \\
Loading rate 2 & 2 & 8.7 & 95 & 1.5 & 3300 \\
Loading rate 3 & 2.75 & 8.6 & 96 & 2 & 4100 \\
\hline
\end{tabular}




\subsection{Analytical methods}

The biogas produced was measured daily by water displacement method and its composition was measured by gas chromatograph. Total solids (TS), volatile solids (VS), pH, alkalinity were determined according to the APHA Standard Methods [8]. Total nitrogen (TN) was estimated by the Kjeldahl method [9].

\section{Results and discussion}

\subsection{Biogas and methane production}

One of the main objectives of this research was to determine the performance of the anaerobic digestion process when operated at different loading rates. For this reason, it was highly important to evaluate process performance in term of biogas composition and production to various loading rates. Production of biogas during anaerobic process at different organic loading rates is shown in Fig. 2. The daily biogas production obtained during run 2 and 3 were approximately $27.6 \mathrm{l} / \mathrm{d}$ and $21.3 \mathrm{l} / \mathrm{d}$ respectively whereas the daily biogas production in run 1 was found approximately $33.3 \mathrm{l} / \mathrm{d}$. Further increase of the organic loading rate as $1.4 \mathrm{kgVS} /\left(\mathrm{m}^{3} . \mathrm{d}\right)$ results in decreased biogas production rates.

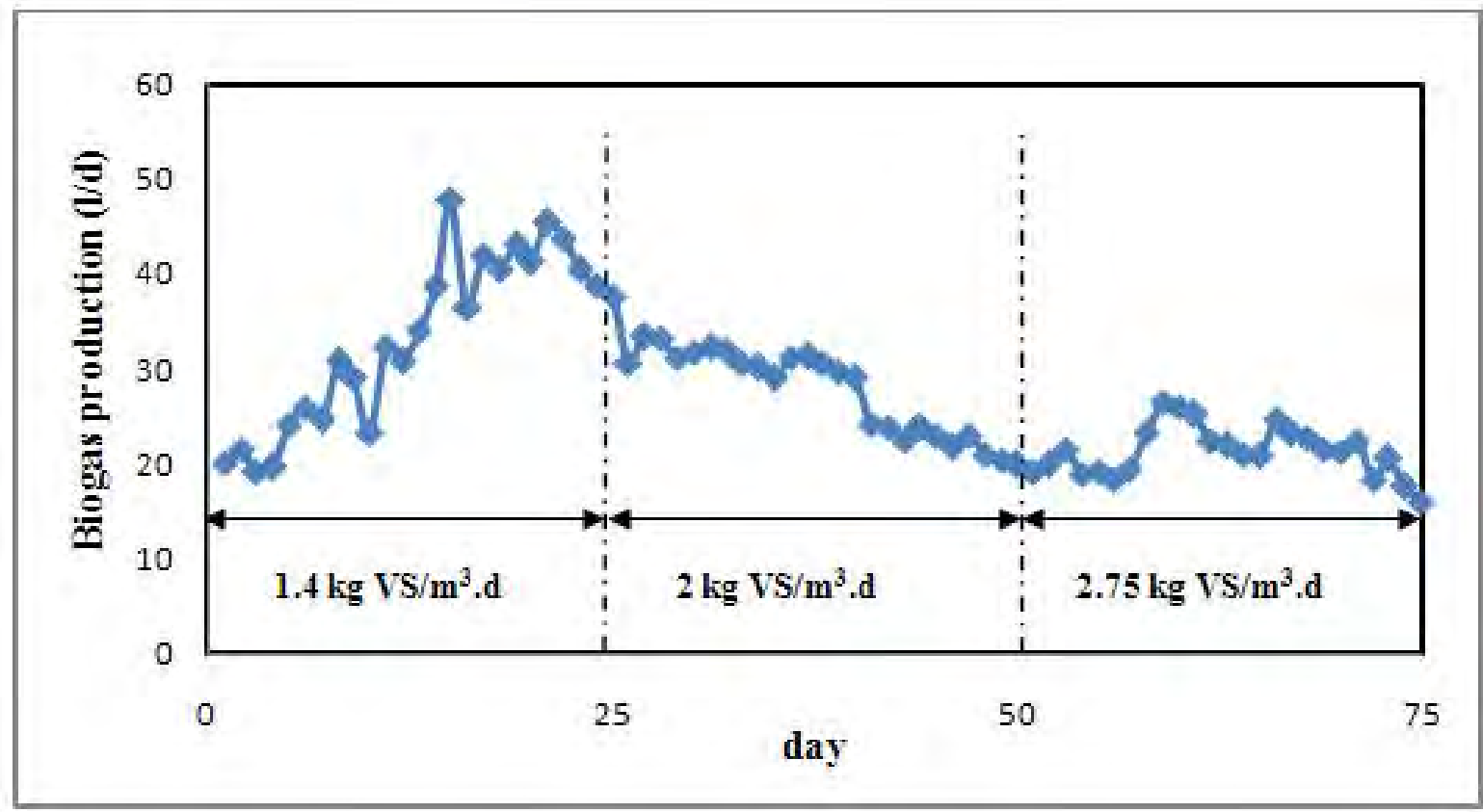

Fig. 2. The amount of biogas production for various loading rates

The reactor showed stable performance with highest methane (64\%) during loading rate of $1.4 \mathrm{kgVS} /\left(\mathrm{m}^{3}\right.$.d). Fig. 3 illustrates the biogas composition. Methane concentration in biogas was observed around $60 \%$ in run 2 whereas it was found less than $49.7 \%$ in run 3 . The measurement of the quantity and composition of the biogas produced in terms of methane and carbon dioxide content is of fundamental importance to evaluate the performance of the process. The increase of carbon dioxide in biogas means that the acidifying microorganisms are prevailing on the methanogens which may lead to volatile fatty acids accumulation.

\subsection{Leachate characteristics}

The stability of the reactor performance was investigated through leachate characteristics analysis besides biogas production and composition. In the anaerobic digestion process, 
methanogenic bacteria are more sensitive to environmental conditions than hydrolytic and acidogenic bacteria.

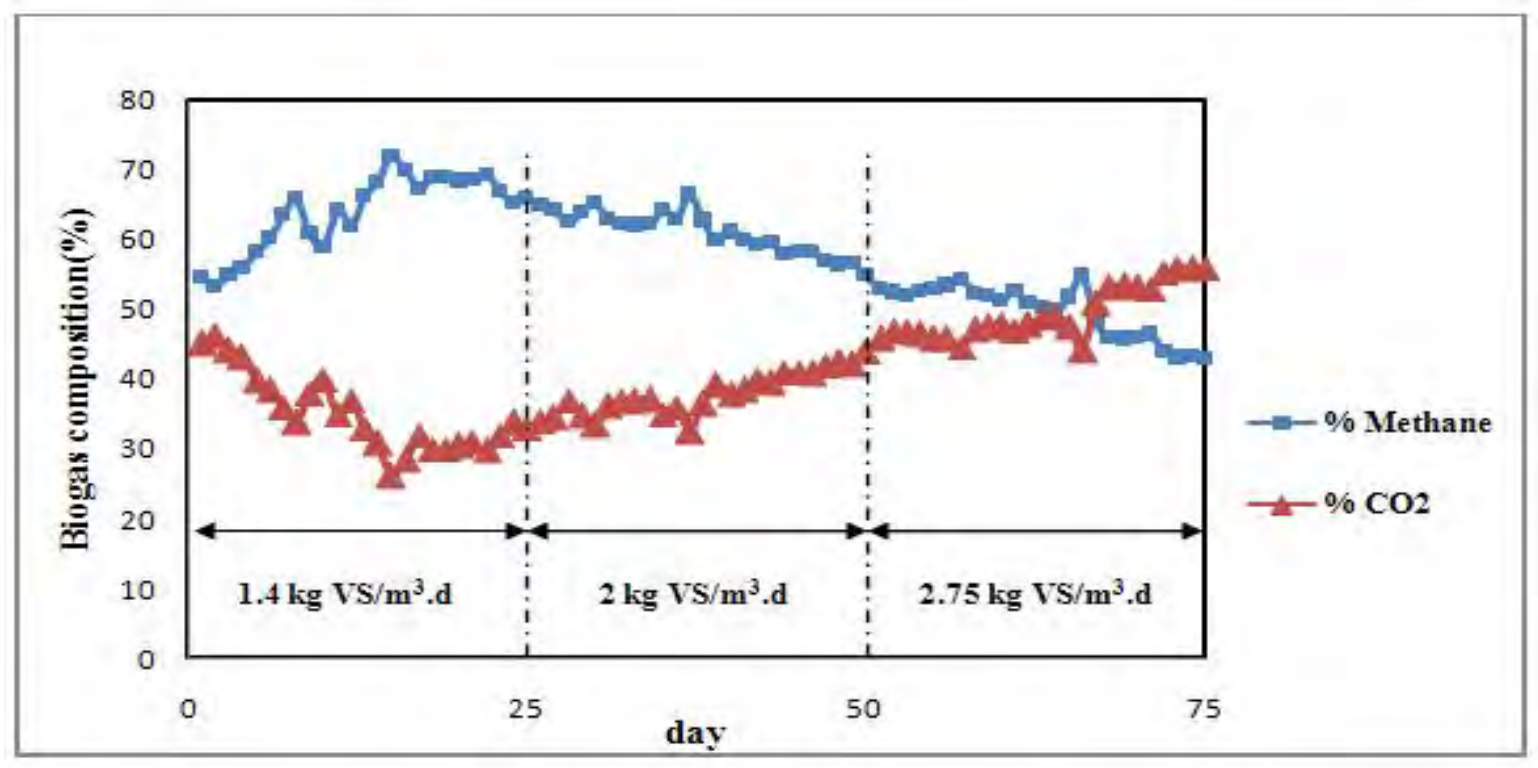

Fig. 3. Biogas composition for various loading rates

Among the environmental conditions, the $\mathrm{pH}$ is the most sensitive parameters. For example, the $\mathrm{pH}$ of digester liquid effluent indicates the stability of the system and its variation also depends on the buffering capacity of the system [10]. The $\mathrm{pH}$ of effluent leachate from the continuous digester remained steady state to the range of 7.75 - 8.0 during the loading rate of $1.4 \mathrm{~kg} \mathrm{VS} / \mathrm{m}^{3}$.d. This shows that the system was well buffered. When the loading rate was increased to $2 \mathrm{~kg} \mathrm{VS} /\left(\mathrm{m}^{3} . \mathrm{d}\right)$, the $\mathrm{pH}$ value dropped from 7.75 and reached to lower value of 7.3 but it was still above 7 which were in the methanogenic range. The methane content in the biogas also dropped and the system showed signs of overloading. As the $\mathrm{pH}$ was in the methanogenic range, the methane content in the biogas was above $60 \%$. Fig.4 illustrates that the $\mathrm{pH}$ in loading rate of $2.75 \mathrm{~kg} \mathrm{VS} / \mathrm{m}^{3}$.d was dropped from 7.3 to 6.8 . Since the $\mathrm{pH}$ is controlled by the volatile organic acids concentration, the alkalinity showed similar trends. This was resolved by immediately stopping the feeding and adding alkaline solution. But the condition could not be recovered during run 3.

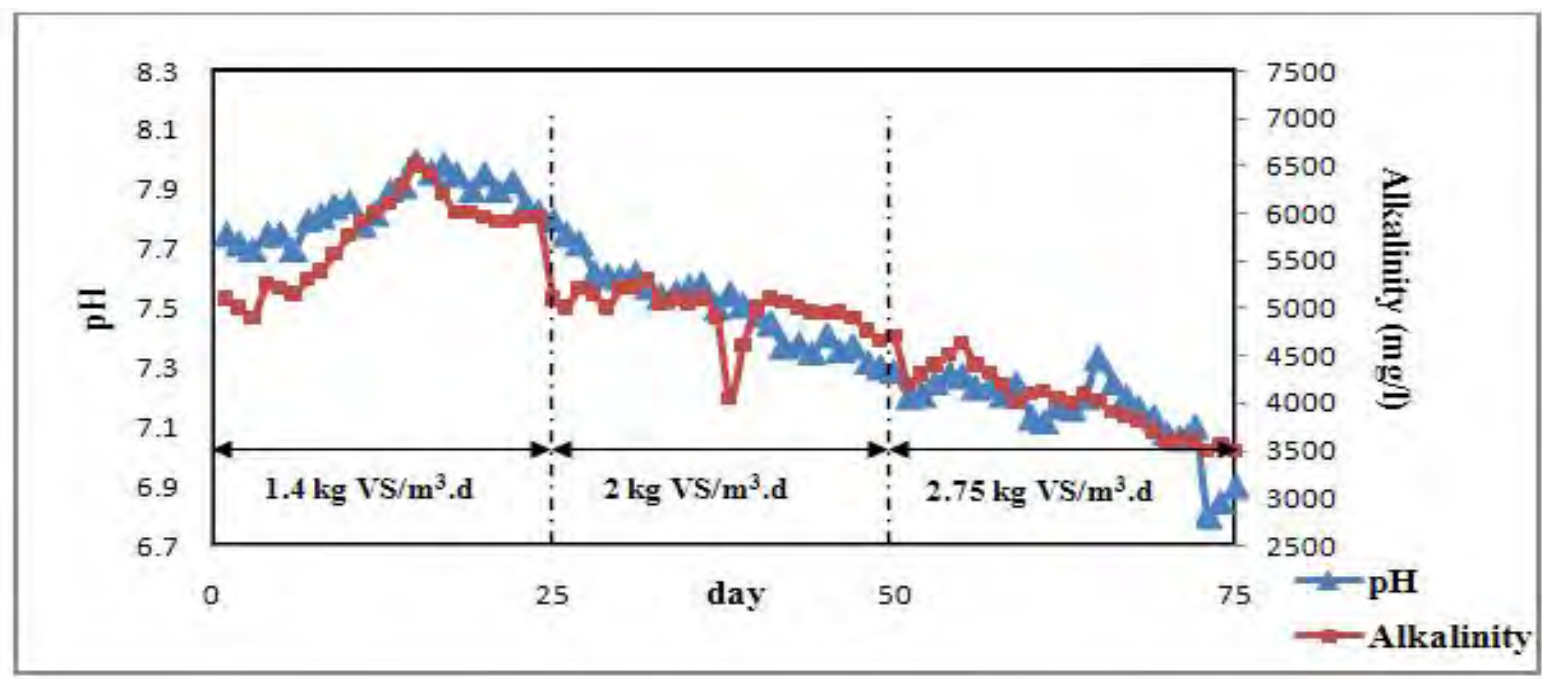

Fig. 4. Values of $p H$ and alkalinity for various loading rates 
In loading rate of $1.4 \mathrm{~kg} \mathrm{VS} /\left(\mathrm{m}^{3} . \mathrm{d}\right)$, the COD concentration was decreased significantly after the completion of the retention time. While in run 2 and 3 higher concentrations of COD were observed. This can be explained that there was higher hydrolysis but less methanogenesis activities. In general hydrolytic bacteria are more robust to environmental condition.

\subsection{Process efficiency}

For the purpose of evaluating the effect of loading rate on the process efficiency, VS reduction and biogas yield were both taken into account as the indicators to assess the reactor performance and efficiency of each loading rate. VS degradation value of $88 \%$ was achieved while operating loading rate $1.4 \mathrm{~kg} \mathrm{VS} /\left(\mathrm{m}^{3} . \mathrm{d}\right)$. This VS reduction is higher compared with the result of 77.1\% reported by Castillo [11]. By increasing the loading rate in run 2 and 3, VS removals were decreased to $80 \%$ and $76 \%$ respectively as illustrated in Fig. 5. The COD degradation was also decreased while organic loadings were increased. In run 1 , the reactor stabilized and the COD was reduced to $65 \%$, which corresponds to high efficiency of COD removal.

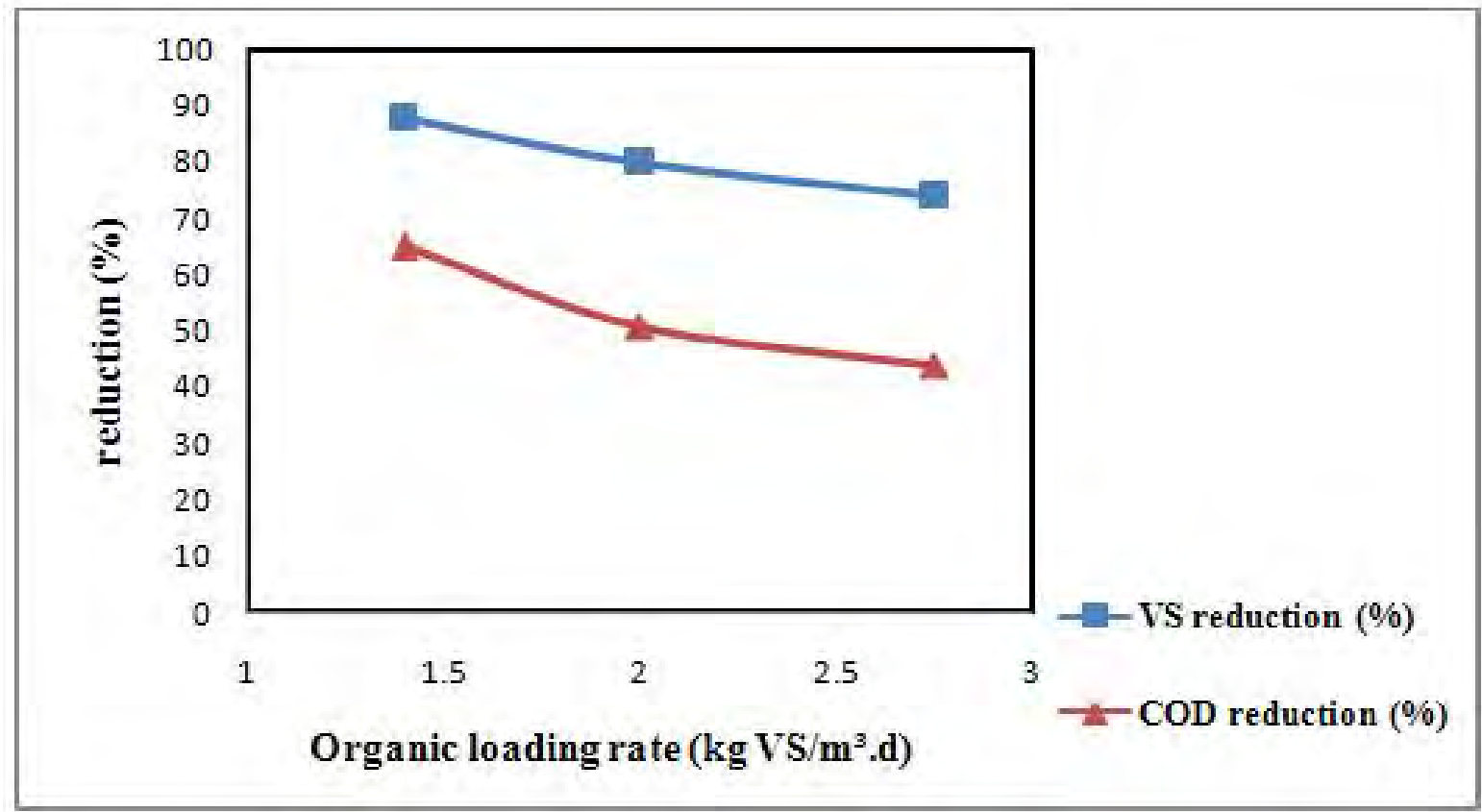

Fig. 5. VS and COD degradation for various organic loading rates

For further illustration, biogas and methane yield for various loading rates are presented in Fig.6. The highest biogas and methane yield observed was $0.4 \mathrm{~m}^{3}$ biogas $/ \mathrm{kg} \mathrm{VS}$ and $0.25 \mathrm{~m}^{3} \mathrm{CH}_{4} / \mathrm{kg}$ VS in run $1\left(1.4 \mathrm{~kg} \mathrm{VS} / \mathrm{m}^{3} . \mathrm{d}\right)$. As the loading rate was increased, a gradual decrease in the biogas production ( 0.22 and $0.12 \mathrm{~m}^{3}$ biogas/kg VS in run 2 and 3 respectively) were observed. The overloading was marked by the fall in $\mathrm{pH}$ and gas yield and increase of carbon dioxide content in the biogas. In this study, the best results were obtained with an organic loading rate of $1.4 \mathrm{~kg} \mathrm{VS} /\left(\mathrm{m}^{3}\right.$.d). The biogas and methane yield of $0.4 \mathrm{~m}^{3}$ biogas $/ \mathrm{kg} \mathrm{VS}$ obtained in this optimum loading rate was found to be satisfactorily successful when compared to literature data which were obtained using fruit and vegetable wastes (Table 2). It should be cautioned here that the optimum loading rate of $1.4 \mathrm{~kg} \mathrm{VS} /\left(\mathrm{m}^{3}\right.$.d) observed here is not universal as the optimal rate depends upon the reactor configuration and other operating conditions. 


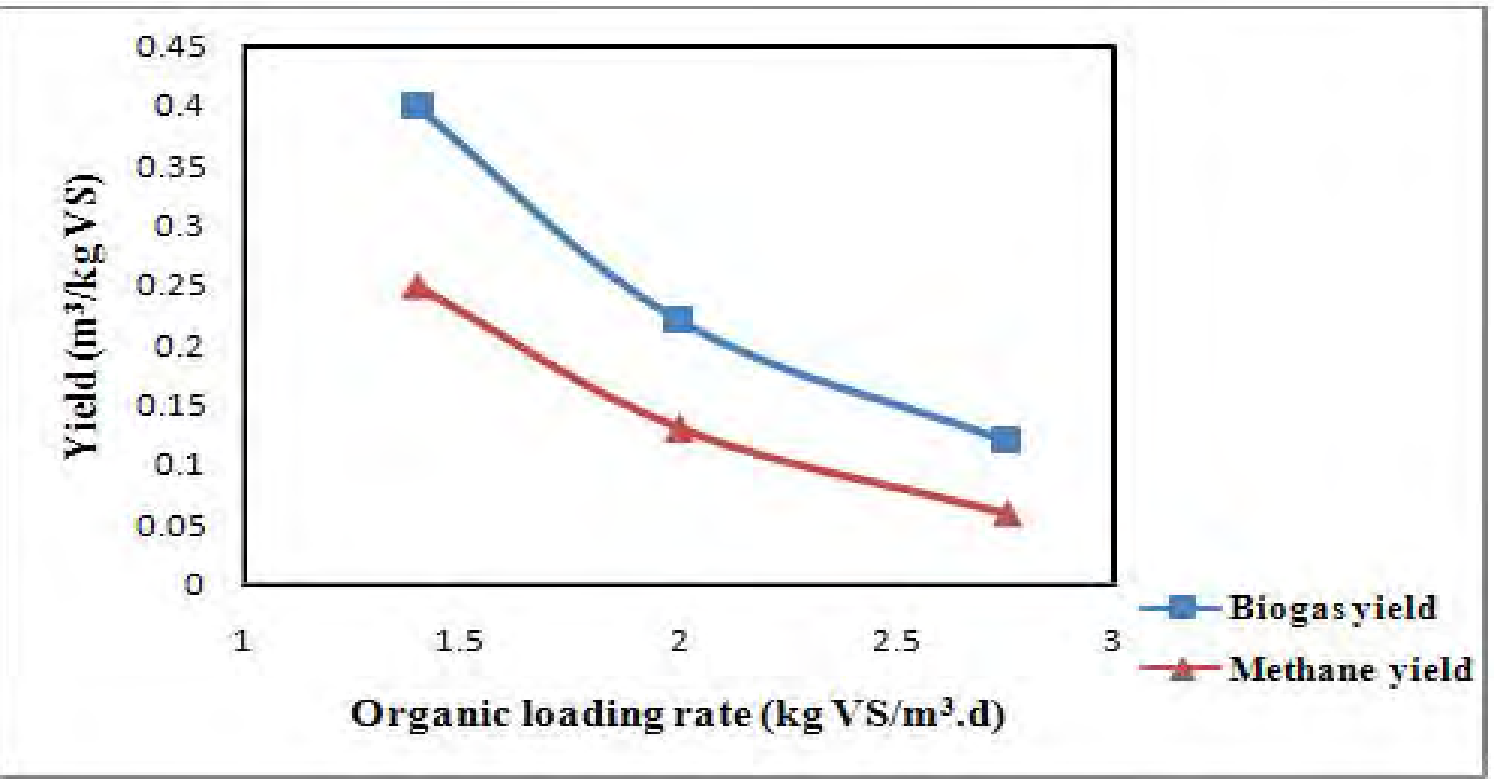

Fig. 6. Biogas and methane yield for various organic loading rates

Table 2. Performance data of different anaerobic process

\begin{tabular}{|c|c|c|c|c|c|}
\hline Substrate & $\begin{array}{c}\text { Organic } \\
\text { loading rates } \\
\left(\mathrm{kg} \mathrm{VS} / \mathrm{m}^{3} . \mathrm{d}\right)\end{array}$ & $\begin{array}{c}\text { Biogas yield } \\
\left(\mathrm{m}^{3} / \mathrm{kg} \text { VS) }\right.\end{array}$ & $\begin{array}{c}\text { Methane } \\
(\%)\end{array}$ & $\begin{array}{c}\text { Degradation } \\
\text { (\% of VS) }\end{array}$ & References \\
\hline $\begin{array}{l}\text { Vegetable } \\
\text { wastes }\end{array}$ & 1.4 & 0.4 & 64 & 88 & Current study \\
\hline $\begin{array}{c}\text { Organic } \\
\text { fraction of } \\
\text { municipal } \\
\text { solid wastes }\end{array}$ & 0.8 & 0.26 & 60 & 61 & [12] \\
\hline $\begin{array}{c}\text { Municipal } \\
\text { solid wastes }\end{array}$ & 2.5 & 0.38 & 61 & 70 & [13] \\
\hline $\begin{array}{l}\text { Fruit and } \\
\text { vegetable } \\
\text { wastes }\end{array}$ & $0.3-1.3$ & 0.3 & $54-56$ & 67 & [14] \\
\hline $\begin{array}{l}\text { Fruit and } \\
\text { vegetable } \\
\text { wastes }\end{array}$ & 1.6 & 0.47 & 65 & 88 & [15] \\
\hline
\end{tabular}

\section{Conclusion}

Anaerobic digestion is promising process for reducing the amounts of biodegradable waste in MSW stream and is also an energy producer from renewable resources. Considering the characteristics of the high-moisture solid waste, anaerobic digestion represents a feasible and effective method to convert the waste to biogas fuel. The reactor showed stable performance with highest methane (64\%) with VS reduction of around 88\% during loading rate of $1.4 \mathrm{~kg}$ $\mathrm{VS} /\left(\mathrm{m}^{3} . \mathrm{d}\right)$. Based on data from this study, OLR of $1.4 \mathrm{~kg} \mathrm{VS} /\left(\mathrm{m}^{3} . \mathrm{d}\right)$ is suggested as design criteria with methane production rate of $0.25 \mathrm{~m}^{3} \mathrm{CH}_{4} / \mathrm{kg}$ VS input. Successful implementation 
of anaerobic digestion as the method of waste treatment leads to the regional utilization of renewable energy resources, as well as the disposal of high moistening content of MSW.

\section{References}

[1] Thorneloe, S.A., Pacey, J.G., Landfill Gas Utilization-Database of North American Projects. Proc. $17^{\text {th }}$ Annual Landfill Gas Symposium, Solid Waste Association of North America, Silver Spring, Maryland, 1994, pp.197-208.

[2] De Baere L. Anaerobic digestion of solid waste: state-of the art. In: Proceedings of the Second International Symposium on Anaerobic Digestion of Solid Waste, Barcelona, Spain, 1999.

[3] Chynoweth DP, Owens JM, Legrand R., Renewable methane from anaerobic digestion of biomass, Renewable Energy, 2001, 22:1-8.

[4] Bouallagui H., Ben Cheikh R., Marouani L., Hamdi M., Mesopholic biogas production from fruit and vegetable waste in a tubular digester, Bioresource Technology, 2003, 86, 85-89.

[5] Hawkes, D.L., Factors affecting net energy production from mesophilic anaerobic digestion. In: Stafford, D.A., Wheatley, B.I., Hughes, D.E. (Eds.), Anaerobic Digestion. Applied Science Publishers Ltd., London, UK, 1980.

[6] Mattocks R., Understanding biogas generation, Technical Paper No. 4.Volunteers in Technical Assistance, Virginia, USA, 1984. p. 13.

[7] Kivaisi AK., Mtila M., Production of biogas from water hyacinth in a two-stage bioreactor, World J Microbiol Biotechnology, 1998, 14, 125-31.

[8] APHA, Standard methods for the examination of water and wastewater, 20th ed. American Public Health Assoc., Washington, DC, 1998.

[9] Greenberg A.E., Clesceri L.S., Eaton A.D., Standard Methods for the examination of water and wastewater, 18th ed. APHA, AWWA, WPCF, Washington, DC, 1992.

[10] Mata-Alvarez, J., Mace, S., and Llabres, P., Anaerobic digestion of organic solid wastes. An overview of research achievement and perspectives, Bioresource Technology, 2000, 74, 3-16.

[11] Castillo M.E.F., Cristancho D.E., Arellano V.A., Study the operational condition for anaerobic digestion of urban solid waste, Waste management, 2006, 26, 546-556.

[12] Nguyen, P.H.L., Kuruparan, P., and Visvanathan, C., 2007. Anaerobic digestion of municipal solid waste as a treatment prior to landfill. Bioresource Technology, 98, 380387.

[13]Fruteau de Laclos, H., Desbois, S., Saint-Joly, C., 1997. Anaerobic digestion of municipal solid organic waste: Valorga full-scale plant in Tilburg, the Netherlands. Water Science and Technology 36 (6-7), 457-462.

[14]Rene Alvarez, Gunnar Liden, 2008. Semi-continuous co-digestion of solid slaughterhouse waste, manure, and fruit and vegetable waste, Renewable Energy, 33, 726-734.

[15] Mata-Alvarez J, Cecchi F, Llabrés P, Pavan P. Anaerobic digestion of the Barcelona central food market organic wastes: experimental study. Bioresour Technol 1992; 39:39_ 48. 